\title{
PEMANFAATAN LIMBAH PETERNAKAN DALAM MENDUKUNG USAHA TANI HORTIKULTURA DI KEBAWETAN KEPAHIANG
}

\section{THE USE OF CATTLE WASTE TO SUPPORT HORTICULTURE FARMING IN KABAWETAN KEPAHIANG}

\author{
Oleh: \\ Jafrizal dan Wismalinda Rita \\ Fakultas Pertanian Universitas Muhammadiyah Bengkulu \\ Email: jafrizalumb@gmail.com danvinnagita@gmail.com
}

\begin{abstract}
Kabawetan sub-district is one of the central areas of plantation, agriculture and animal husbandry in the province of Bengkulu. In running their farm, farmers still use conventional system, especially the use of anorganic fertilizer (chemical factory) and overused pesticide. Besides as a farmer, almost in every village people also seek beef cattle and dairy cattle. Farm waste already started causing environmental problems for society, while on the other hand they have difficulty in getting the fertilizer for business continuity (horticultural crops). With input from the farmers, we agreed to offer a solution using animal waste into organic fertilizer. The form of such activities carry out: education and counseling about environmental friendly agriculture; as well as training in the making Bokashi and biourine. Later stage is making plots experiment to apply organic fertilizer produced vegetable plants. This community service activity has been done and able to reduce farmers' dependence on chemical fertilizers and chemical pesticides, and also revive local knowledge in farming. From the aspect of production, horticultural products (vegetables) produced by farmers are more environmental friendly.
\end{abstract}

Keywords: Horticulture, Bokashi, Biourine, Organic Farming

\section{PENDAHULUAN}

Kecamatan Kebawetan adalah salah satu delapan kecamatan yang ada di Kabupaten Kepahiang dengan luas daerah 6.331 ha atau hampir $10 \%$ dari luasan kabupaten secara keseluruhan. Ibu kecamatan berjarak $10 \mathrm{~km}$ dari ibu kabupaten dan $75 \mathrm{~km}$ dari ibu kota Provinsi Bengkulu. Konturnya berbukit, suhu rata-rata $16-28{ }^{\circ} \mathrm{C}$ dengan tingkat kelembaban $70-80 \%$. Kondisi alam yang berbukit dan sejuk ini menjadikan Kecamatan Kebawetan sebagai salah satu sentral perkebunan (kebun Teh Kebawetan), pertanian dan peternakan yang terkemuka tidak hanya di Kabupaten Kepahiang tapi untuk Provinsi Bengkulu secara keseluruhan.

Usaha pertanian yang utama adalah usaha tani padi sawah, palawija dan tanaman holtikultura (sayur-mayur). Produk palawija yang menonjol diantaranya jagung pakan ternak, jagung manis dan ubi-ubian. Produk holtikultura adalah berbagai jenis sayur-mayur diantaranya cabe, kentang, pisang, tomat, kol, terong, wortel, buncis, bawang daun, seledri, 
labu siam, kacang buncis, kacang panjang dan lain-lain. Realisasi penanaman tanaman sayuran di Kecamatan Kebawetan pada tahun 2012 lalu diantaranya wortel 15 ha, kubis 18 ha, sawi 10 ha, kacang buncis 20 ha, kacang panjang 11 ha dan ubu jalar 25 ha (Anonim, 2013).

Sektor peternakan di Kabupaten Kepahiang juga tumbuh dengan pesat, menurut data dari Dinas Peternakan Kabupaten Kepahiang (Anonim, 2012) di Kecamatan Kebawetan tercatat ada 2.203 ekor sapi potong, 36 ekor sapi perah dan 125 ekor kerbau. Khusus di Kecamatan Kepahiang usaha penggemukan sapi potong hampir merata diusahakan oleh petani pada setiap desa sebagai usaha sampingan.

Sebagaimana usaha tani umumnya, para petani holtikultura di Kecamatan Kebawetan masih mengusahakan usaha taninya dengan cara-cara yang konvensional. Para petani masih menggantungkan usahanya pada pupuk buatan (kimia pabrik) dan pestisida dalam mengendalikan organisme pengganggu tanaman (OPT).

Pemakaian pupuk buatan (kimia pabrik) dan pestisida hasil berbagai hasil penelitian terbukti telah banyak menimbulkan dampak negatif. Produktivitas lahan menjadi menurun karena pupuk kimia menyebabkan tanah menjadi asam, padat, mengganggu kegiatan mikroorganisme yang ada di tanah, dan lain-lain. Dari aspek lingkungan pemakaian pupuk buatan dan pestisida juga telah terbukti mencemari perairan (air tanah ataupun air permukaan), tanah, dan juga mencemari produk pangan yang dihasilkan. Dari aspek ekonomi pemakaian pupuk buatan dan pestisida yang dulu dicanangkan dengan semboyan panca usaha tani juga terbukti telah menimbulkan ketergantungan petani akan produk pabrik dan mematikan beberapa kearifan lokal dalam usaha tani yang dulu pernah ada di lingkungan masyarakat tani kita. Dengan tingkat harga pupuk ditingkat petani yang cendrung tinggi dan dengan tingkat ketersediaan yang sering mengalami kelangkaan maka hal ini menjadi permasalahan yang serius dialami oleh petani hortikultura yang ada di Kecamatan Kabawetan.

Sektor peternakan di Kecamatan Kebawetan saat ini gencar digalakkan oleh pemerintah daerah Kabupaten Kepahiang dengan menjadikannya menjadi salah satu produk unggulan daerah, dan mendapat sambutan positif dari masyarakat petani. Disamping telah menelurkan berbagai keberhasilan dan prestasi, usaha penggemukan sapi potong dan sapi perah pada kenyataannya juga telah menimbulkan beberapa masalah. Salah satu masalah yang timbul dan dirasakan berat oleh masyarakat peternak adalah limbah padat dan cair yang semakin lama semakin tinggi jumlahnya seiring dengan perkembangan usaha ternak di daerah tersebut. Secara teoritis, satu ekor sapi dewasa akan menghasilkan limbah padat (feses) sebanyak 8-11 kg/hari serta limbah cair (urine) sampai 25 lt/hari. Dengan populasi sapi yang cukup tinggi dapat dibayangkan apa yang terjadi bila kedua jenis limbah tersebut tidak tertangani dengan baik.

Selama ini baru limbah padat (feses) yang baru dimanfaatkan oleh petani peternak sebagai pupuk organik untuk usahatani holtikultura mereka. Walaupun sudah termanfaatkan, akan tetapi belum dapat memenuhi kebutuhannya akan pupuk organik karena secara alami feses segar akan butuh waktu yang relatif lama menjadi pupuk matang yang siap diaplikasikan terhadap tanaman. Keberadaan feses segar yang cukup lama 
disekitar kandang akan membutuhkan tempat yang cukup luas dalam penyimpanan dan proses pematangannya.

Sementara untuk limbah cair terutama urine sapi, karena keterbatasan pengetahuan dan keterampilan, mereka sama sekali belum memanfaatkannya dan dibiarkan menjadi limbah yang merusak terhadap lingkungan. Mereka masih beranggapan bahwa urine sapi panas dan berdampak tidak baik terhadap tanaman.

Mengingat limbah ternak (feses dan urine sapi) saat ini sudah mulai menimbulkan dampak negatif dan menjadi salah satu permasalahan serius bagi peternak sapi di Kecamatan Kebawetan, sementara disisi lainnya mereka justru kesulitan untuk mendapatkan pupuk yang sangat dibutuhkan bagi keberlanjutan usaha pokok mereka (holtikultura), maka dirasa sangat tepat bila limbah tersebut bisa diolah menjadi produk pupuk organik yang memiliki nilai tambah, murah, dan lebih ramah terhadap lingkungan. Agar solusi yang telah disepakati lebih mudah diterima dan diserap oleh masyarakat petani maka teknologi yang dipilih haruslah sederhana, murah, berbasis pada potensi lokal, serta lebih ramah terhadap lingkungan.

Kotoran sapi (feses dan urine) sebagai limbah organik, merupakan bahan yang sangat baik untuk pembuatan pupuk organik padat (bokashi) maupun pupuk organik cair (biourine). Menurut Lingga (1991) kandungan zat hara yang terdapat dalam feses sapi adalah $0,40 \% \mathrm{~N}, 0,20 \% \mathrm{P}$, dan $0,10 \% \mathrm{~K}$, sementara di dalam urinnya tengandung $1,00 \%$ $\mathrm{N}, 0,50 \% \mathrm{P}$ dan $1,50 \% \mathrm{~K}$. Dalam prakteknya nanti, untuk merobah feses dan urine sapi menjadi pupuk organik akan ditempuh melalui proses fermentasi.

Menurut Rahman (1989), fermentasi merupakan aktivitas mikroorganisme baik aerob maupun anaerob yang mampu mengubah atau mentransformasi senyawa kimia ke substrat organik. Dengan proses fermentasi limbah pada (feses) sapi dapat dimanfaatkan menjadi pupuk organik berupa kompos (bokashi), sementara urine diproses (difermentasi) menjadi pupuk cair dengan kandungan hara tinggi (biourine).

\section{METODE PENGABDIAN}

\section{Pendidikan dan Penyuluhan}

Untuk menambah wawasan anggota kelompok tani dilakukan melalui pendidikan dan penyuluhan tentang manajemen ternak potong dan perah, pertanian ramah lingkungan, dan pengetahuan tentang pembuatan bermacam-macam pupuk organik yang berbasiskan potensi lokal dan ramah lingkungan.

\section{Pelatihan}

Berdasarkan permasalahan dan solusi yang telah disepakati, maka anggota kelompok tani sasaran akan dilatih dalam proses pembuatan bokashi dan biourine.

\section{a. Pembuatan Bokashi}


Cara pembuatan bokashi diawali dengan pembuatan larutan dekomposer untuk setiap $150 \mathrm{~kg}$ kotoran ternak, yaitu dengan melarutkan 1 liter aktivator EM4 dan 0,25 kg gula merah kedalam 10 liter air, lalu ditutup rapat dalam stoples dan diamkan selama 1 hari. Hamparkan kotoran ternak sapi dengan ketebalan $20 \mathrm{~cm}$ lalu taburi dedak halus, sekam padi, lalu siram dengan larutan dekomposer yang telah diencerkan dengan air, diaduk dengan cangkul sambil ditumpuk. Lakukan cara yang sama hingga tumpukan mencapai 1,5 meter. Lalu ditutup dengan terpal dan diamkan selama 3 minggu, lakukan pembalikan seminggu sekali. Setelah 3 minggu suhu akan turun dan bokashi dikering anginkan, diayak dan sudah siap untuk pengemasan ke dalam karung.

\section{b. Pembuatan Biourine}

Proses pengolahan urine sapi dilakukan dengan mencampur setiap 100 liter urine sapi dengan fitobiotik (1 kg lengkuas, $1 \mathrm{~kg}$ kunyit, $1 \mathrm{~kg}$ jahe, $1 \mathrm{~kg}$ kencur dan $1 \mathrm{~kg}$ temulawak), dan 1 lt bioaktivator (EM4). Semua bahan yang sudah tercampur dimasukkan dalam beberapa tong berpenutup lalu difermentasi/didiamkan selama 14 hari. Penambahan empon-empon (fitobiotik) ditujukan untuk menghilangkan bau khas urine dan sekaligus sebagai pestisida alami yang tidak disukai organisme pengganggu tanaman (OPT). Setelah 14 hari biourine disaring dan siap untuk dikemas ke dalam derigen.

\section{Demplot Percobaan}

Dari hasil kedua tahapan di atas, petani yang sudah dilatih membuat bokashi dan biourine akan dibimbing dan didampingi dalam mengaplikasikan pupuk organik yang dihasilkan pada usaha tani holtikultura (sayur-mayur) yang menjadi usaha pokok mereka. Pupuk bokhasi diberikan dengan dosis 3 ton/ha, sementara biourine disemprotkan saat tanaman berumur 2-3 minggu dan pada fase primordial dimana tanaman sudah mulai ada yang mengeluarkan bunga. Berhubung karakteristik pupuk organik yang lebih lambat dampaknya terhadap hasil tanaman, maka untuk tahap awal pemakaian pupuk anorganik tetap dengan dosis biasa dan berangsur-angsur dikurangi pada setiap musim tanam.

\section{HASIL DAN PEMBAHASAN}

\section{Persiapan}

Pada tahap persiapan yang telah dilakukan antara lain pengurusan perizinan dan koordinasi dengan kedua kelompok tani mitra kegiatan pengabdian. Perizinan dimulai dengan mengurus surat pengantar dari LPPM Universitas Muhammadiyah Bengkulu yang ditujukan ke Kepala Desa Sukasari dan Kepala Desa Mekar Sari Kecamatan Kebawetan Kabupaten Kepahiang.

Setelah minta izin kepala desa, selanjutnya tim pelaksana kegiatan pengabdian melakukan koordinasi dengan kedua mitra. Koordinasi dilakukan dengan kedua Ketua Kelompok Tani Sumber Mulya (Bapak Tarsan) dan Janur Wenda (Bapak Yahudi, S.Pd). Dalam koordinasi dengan kedua mitra hal-hal yang dibicarakan antara lain waktu 
pelaksanaan, tempat pembuatan bokashi dan biourine, lokasi demplot percobaan, dan bahan dan alat yang dibutuhkan dalam pelaksanaan kegiatan pengabdian.

Dalam diskusi juga diminta masukan dari kedua kelompok tentang tahapan dan metode pelaksanaan kegiatan. Dari beberapa kali koordinasi yang telah dilakukan, didapat kesepakatan diantaranya kegiatan pendidikan dan penyuluhan dipusatkan di lokasi Kelompok Tani Sumber Mulya, sementara untuk kegiatan pelatihan pembuatan bokashi dan biourine, demplot percobaan dilakukan pada kedua lokasi kelompok tani. Pertemuan juga menyepakati bahwa semua kegiatan hanya diikuti oleh perwakilan kedua kelompok yang masing-masing 5 orang per kelompok kecuali pada kegiatan penyuluhan yang boleh diikuti oleh seluruh anggota kelompok mitra.

Pada saat koordinasi dengan tim juga diinformasikan bahwa kegiatan pengabdian ini tidak hanya dihadiri oleh tim inti pelaksana kegiatan yaitu dua orang dosen, akan tetapi direncanakan juga akan melibatkan mahasiswa dan alumni Fakultas Pertanian Universitas Muhammadiyah Bengkulu terutama yang berdomisili di sekitaran Kabupaten Kepahiang. Hal ini dilakukan disamping untuk menambah wawasan mahasiswa dalam praktek usaha peternakan dan pertanian, juga ditujukan sebagai ajang promosi bagi Universitas Muhammadiyah Bengkulu terutama bagi prodi-prodi yang ada di lingkungan Fakultas Pertanian. Sementara alumni dilibatkan agar terjalin silaturahim antara alumni dengan juniornya dan staf pengajar (dosen) disamping juga dapat memberikan masukan dalam pelaksanaan kegiatan pengabdian.

Setelah melakukan koordinasi dan kesepakatan dengan kedua kelompok, tim pelaksana kegiatan mulai menyiapkan alat dan bahan. Alat-alat yang dibeli/dipesan diantaranya spanduk, guci besar, ember, derigen, timbangan, saringan, corong plastik, terpal, cangkul, skop, gerobak, dll. Bahan-bahan diantaranya dedak padi, dedak kopi, sekam padi, empon-emponan, gula merah, EM4, kapur, pupuk buatan, bibit tanaman, dll. Sementara kotoran sapi (feses) dan urine sapi disiapkan oleh mitra.

Berhubung karena banyaknya macam alat dan bahan kegiatan serta beberapa volume alat yang besar (seperti kendi, ember, derigen dan gerobak dorong), maka droping alat ke lokasi mitra harus dilakukan dalam beberapa kali keberangkatan.

\section{Pendidikan dan Penyuluhan}

Sesuai dengan kesepakatan sebelumnya dengan kelompok tani mitra, kegiatasan penyuluhan hanya difokuskan pada satu lokasi mitra yaitu di ruang pertemuan Kelompok Tani Sumber Mulya Desa Sukasari. Tempat ini dipilih karena kelompok mitra ini memiliki ruang pertemuan yang cukup praktis dan lebih dekat dengan kandang ternak sapi potong milik Kelompok Tani Sumber Mulya sehingga sangat mendukung dalam diskusi antara pemateri dan peserta pelatihan. 
Pelatihan diisi dengan materi yang berkaitan dengan topik pengabdian diantaranya managemen sapi potong dan perah, dan pertanian ramah lingkungan dan pupuk organik. Acara penyuluhan diawali dengan presentasi dari tim pelaksana dan dilanjutkan dengan diskusi/tanya jawab. Acara dikondisikan akrab dan penuh kekeluargaan. Alat bantu yang digunakan disamping fotocopian makalah juga didukung dengan tampilan powerpoint menggunakan LCD projektor. Tim pelaksana, petani mitra, alumni dan mahasiswa terlibat dalam diskusi yang menarik. Dalam diskusi juga dibahas potensi bahan organik apa saja yang ada disekitaran petani peternak yang bisa dimanfaatkan sebagai pupuk organik. Agar sesuai dengan kondisi riil, diskusi dilanjutkan lagi di lokasi kandang sapi potong yang hanya berjarak 100 meter dari lokasi.

\section{Pelatihan Pembuatan Bokashi}

Kegiatan pelatihan pembuatan bokashi diawali dengan penjelasan dan diskusi tentang alat, bahan dan metoda yang akan dilakukan. Dalam diskusi juga dibicarakan beberapa metode yang bisa diterapkan dalam pembuatan kompos (bokashi) maupun pembuatan biourine. Masing-masing metode dibahas kelebihan dan kekurangannya. Petani dibebaskan untuk memilih metode pembuatan yang paling mudah/gampang versi mereka, dengan tetap memperhatikan kaedah ilmu dan teknologi pembuatan pupuk organik. Masukan petani ini penting agar petani merasa dihargai, punya kontribusi, dan yang lebih adalah terciptanya keberlanjutan dari program pengabdian pasca kegiatan resmi.

Berhubung dengan kondisi iklim yang kurang mendukung (hujan), maka kegiatan pembuatan bokashi hanya dilakukan satu kali proses, tetapi dengan harapan petani dengan mandiri bersama kelompoknya akan membuat lebih banyak lagi kompos karena bahan baku yang berlimpah (feses sapi). Untuk mendampingi petani, tim meminta kesediaan salah satu alumni yang kebetulan putra daerah setempat yang juga sudah pernah ikut pelatihan pembuatan bokashi di bangku kuliah.

\section{Pelatihan Pembuatan Biourine}

Pelatihan pembuatan biourine merupakan materi kegiatan yang paling menarik dan diminati oleh anggota kelompok tani mitra. Dari diskusi terungkap bahwa mereka sudah lama berhasrat untuk memanfaatkan urine sapi yang selama ini belum sedikitpun termanfaatkan, bahkan dirasakan sebagai sesuatu limbah yang mencemari lingkungan mereka. Sebelum adanya rencana kegiatan pengabdian ini, mereka sudah berusaha mencari informasi pembuatan biourine sampai ke Bandung Jawa Barat. Bahkan mereka sudah berencana untuk mendatangkan tenaga terampil dari pulau jawa untuk melatih mereka dalam memanfaatkan urine sapi menjadi pupuk organik cair (biourine).

Sebelum kegiatan pelatihan dilaksanakan, sudah disepakati para petani akan mengumpulkan urine sapi kedalam guci yang sudah didroping sebelumnya. Anggota Kelompok Tani Sumber Mulya mengumpulkan urine sapi dengan metode ditampung langsung dengan ember saat ternak sapi kencing. Hal ini bisa dilakukan karena mereka memelihara sapi perah yang lebih intensif pemeliharaannya dengan kandang yang juga lebih bersih dan representatif dibandingkan dengan ternak sapi potong. Sementara petani 
pada Kelompok Tani Janur Wendo mengumpulkan urine dengan metode mengumpulkan dari siring yang terdapat di belakang kandang sapi. Akibat metode pengumpulan urine yang berbeda tadi maka tingkat kemurnian urine juga berbeda, dimana metode tampung akan diperoleh urine murni, sementara dengan metode pengumpulan di dalam siring urine sudah tercampur dengan feses sapi.

Pembuatan biourine diawali dengan menggiling empon-emponan kemudian langsung dicampurkan kedalam urine di dalam guci. Di tempat terpisah gula aren dan tetes tebu diencerkan dengan 10 liter air untuk membuat larutan EM 4, yang selanjutnya diaduk bersama urine di dalam guci lebih kurang 10-15 menit. Guci lalu ditutup plastik dan diikat dengan tali karet bekas ban dalam kendaraan. Pengadukan dilakukan setiap hari dan diharapkan jadi pupuk cair dalam waktu satu sampai dua minggu.

\section{Pembuatan Demplot Percobaan}

Setelah petani menguasai dan memahami teknologi pembuatan bokashi dan biourine, mereka selanjutnya juga dicobakan dan dibiasakan dalam memanfaatkan pupuk organik dimaksud. Agar petani lebih mudah menerima dan mengadopsi pupuk organik ini (terutama biourine), maka aplikasi terhadap tanaman sayuran dilakukan secara bertahap. Pada tahap awal pupuk organik hanya dipakai sebagai pupuk pelengkap dan mereka masih diizinkan kalau masih mau tetap menggunakan pupuk dan pestisida anorganik. Secara perlahan dan pasti mereka akan digiring untuk lebih banyak menggunakan pupuk organik atau kalau mungkin meninggalkan sama sekali pupuk anorganik.

Pada tahap awal sesuai kesepakatan pupuk organik yang telah diproduksi hanya diaplikasikan pada tanaman bawang daun dan sawi hijau. Kedua tanaman sayuran ini dipilih untuk mengurangi resiko gagal panen para petani karena memakai metode baru dalam berproduksi yang masih asing bagi mereka (terutama penyemprotan dan penyiraman biourine).

Pupuk organik diberikan dengan dosis 3 ton/ha, sementara biourine yang sudah diencerkan dengan air, disiramkan serta disemprotkan langsung ke permukaan daun tanaman dengan interval 2 minggu sekali.

\section{Evalusi Kegiatan}

Seiring dengan berjalannya waktu, semua kegiatan yang sudah berjalan dievaluasi terutama proses pembuatan bokashi dan biourine yang sudah dipraktekan.

Pada tahap awal pembuatan pupuk bokashi, pupuk bokashi yang dihasilkan oleh kelompok tani Sumber Mulya kualitasnya baik sesuai harapan, akan tetapi bokashi yang dibuat oleh kelompok tani Janur Wendo terdapat gumpalan-gumpalan. Setelah dilakukan evaluasi dan diskusi dengan anggota kelompok, hal ini disebabkan oleh karena bokashi yang dibuat dalam volume yang banyak sehingga kurang sempurna dalam pembalikan dan pengadukan sehingga tidak terdekomposisi dengan sempurna. Kekurangan ini telah dapat diatasi dalam produksi bokashi selanjutnya. 
Kendala lainnya, tiga minggu setelah tanam benih sawi hijau yang langsung ditanam di lahan demplot percobaan pertumbuhannya tidak optimal dan banyak yang mati. Dari hasil analisis dilapangan dan masukan dari petani, hal ini diduga disebabkan oleh sangat kurangnya curah hujan karena penanaman dilakukan di puncak musim kemarau (Agustus) sementara sawi merupakan tanaman berdaun lebar yang banyak membutuhkan air dalam pertumbuhannya. Untuk mengurangi kerugian petani disepakati untuk menambah/menyisip lahan demplot percobaan dengan tumpang sari tanaman wortel. Menurut pernyataan petani tanaman tumpang sari wortel yang dipupuk dengan bokashi dan disemprot biourine pertumbuhannya lebih baik dari pada musim tanam sebelumnya.

Dari pertemuan dengan anggota kelompok tani di akhir kegiatan diperoleh informasi bahwa produk bokashi tidak hanya untuk memenuhi kebutuhan anggota, akan tetapi sebagian juga sudah dijual ke petani lain. Bahkan menurut ketua kelompok tani Sumber Mulya, mereka sudah ada tawaran dari perkebunan teh Kebawetan untuk membeli produk pupuk bokashi mereka. Dari hal ini dapat disimpulkan bahwa produk bokashi yang telah dihasilkan disamping telah dipakai untuk kebutuhan usaha tani anggota kelompok, juga sudah dapat memberikan pemasukan tambahan bagi anggota kelompok tani.

\section{Pendampingan}

Pendampingan dilakukan agar petani merasa terbimbing dan percaya diri dalam menerapkan pertanian yang lebih ramah lingkungan (pupuk organik) dalam memproduksi tanaman sayuran. Pendampingan langsung di lapangan dilaksanakan sampai berakhirnya kegiatan pengabdian (bulan Oktober), sementara setelah berakhir program pendampingan dilakukan melalui media komunikasi (lisan) dan dengan mengerahkan beberapa orang alumni yang kebetulan adalah putra daerah setempat.

\section{KESIMPULAN}

Dari pelaksanaan program pengabdian kepada masyarakat yang telah dilaksanakan dapat diambil kesimpulan:

1) Petani telah mampu mengolah limbah ternak menjadi pupuk organik padat (bokashi) dan pupuk organik cair (biourine).

2) Petani telah mampu mengaplikasikan pupuk organik yang dibuatnya ke tanaman sayuran yang menjadi usaha tani pokoknya.

3) Pertumbuhan tanaman sayuran dengan pupuk bokashi dan biourine lebih baik.

4) Ketergantungan petani kepada pupuk anorganik sudah berkurang, bahkan pembuatan pupuk organik bokashi bisa memberikan penghasilan tambahan bagi anggota kelompok tani dengan menjualnya kepada petani lain maupun perkebunan swasta (kebun teh). 


\section{DAFTAR PUSTAKA}

Anonim, 2013, Laporan Realisasi Tanaman Holtikultura di Kabupaten Kepahiang Tahun 2012, Badan Penyuluhan Pertanian, Peternakan, Perikanan dan Kehutanan (BP3K) Kabupaten Kepahiang.

Anonim, 2012, Laporan Dinas Peternakan Kepahiang 2012, Kepahiang.

Lingga, 1991, Petunjuk Penggunaan Pupuk, Penebar Swadaya, Jakarta.

Rahman, A., 1989, Pengantar Teknologi Fermentasi, PAU Pangan dan Gizi, IPB, Bogor. 